Final Draft

\title{
Sociocultural Perspectives on Teacher Language Awareness in Form-Focused EFL Classroom Instruction
}

Jasmine C.M. Luk ${ }^{a,{ }^{*}}$, Ruth M.H. Wong ${ }^{b}$

${ }^{a}$ Division of English Language Education, Faculty of Education, The University of Hong Kong

${ }^{b}$ Department of English, The Hong Kong Institute of Education

\begin{abstract}
A teacher's language awareness (TLA) is generally believed to have a significant impact on grammar or form-focused (FonF) instruction. TLA has traditionally been assumed to be a cognitive construct. A more recent view on TLA argues for its sociocultural significant in second language learning. This paper builds on this recent view and attempts to illuminate the need to incorporate sociocultural perspectives on TLA in FonF instruction. Through a micro-analysis of four naturally occurring FonF instructional episodes from a Hong Kong EFL classroom, we identify problems with the teacher's form-focused instructional discourse and discuss how these problems may have revealed the teacher's lack of awareness of the sociocultural nature of form-meaning connections, the role of learners’ previous embodied experiences as meaning-makers, and of the need to establish intersubjective understanding with the learners about the multiple texts and contexts that the learners might be drawing on in the meaning-making process. Implications will be drawn with a view to facilitating EFL teachers’ form-focused instructional discourse.
\end{abstract}

\section{Introduction}

The recently revived interest in form-focused (FonF) instruction among psycholinguistic-oriented second language acquisition (SLA) researchers distinguishes itself from the traditional structural approach to grammar instruction by seeing language forms as meaning-potential resources (VanPatten, Williams, Rott, and Overstreet, 2004) as opposed to seeing language forms as decontextualized linguistic properties to be acquired for the sake of formal accuracy. Most studies on form-focused instruction adopt an experimental approach to investigate the effectiveness of instructional strategies that often appear in binary forms (for example, proactive/reactive, targeted/general, extensive/intensive, inductive/deductive; obtrusive/unobtrusive, etc., see the review by Williams, 2005). Very few of these studies have attempted to analyze the discourse of form-focused instruction and its impact on learning in second language classrooms. The current paper reports on 
Final Draft

findings from a micro-analysis of naturally-occurring form-focused instructional episodes in a Hong Kong EFL classroom. Of particular concern in our analysis is the need to consider sociocultural perspectives on FonF instruction by acknowledging the role of learners' previous experiences of communication in contextualized sense-making of the form-meaning connections. We will argue that such sociocultural perspectives of FonF instruction should be highlighted as part of EFL teachers' language awareness (TLA).

\section{Perspectives on FonF instruction: from cognitive to sociocultural}

Many mainstream psycholinguistic-oriented second language acquisition (SLA) researchers hold that SLA is the learning of form-meaning connections (FMCs), or constructions that relate form and meaning (Ellis, 2004). This has led to a growing awareness that language forms should be acquired as meaning-potential linguistic resources rather than as decontextualized discrete linguistic items aimed at achieving only formal accuracy. According to VanPatten et al. (2004), the meaning aspect of the construction of FMCs is believed to "reside" in the lexicon (p.13, quotations in original). FMCs research, therefore, is most widely done in the areas of lexical acquisition and those grammatical features (such as the tense-aspect system) that are often expressed through lexical items. In the FMCs configuration, form and meaning do not always demonstrate a one-to-one relationship. Three possible connections are mentioned in VanPatten et al. (2004), namely (1) one form encodes one meaning; (2) one form encodes multiple meanings in different contexts, or in a single context; and (3) multiple forms encode the same meaning. For example, pastness in English can be encoded by temporal lexical items such as “yesterday”, "before” as well as bound and unbound morpheme (“was”, “-ed”). Even though the variant nature of form-meaning connections is acknowledged, the theory itself implies that there is an established and 
mutually shared and agreed-upon sets of FMCs available in the form of a data bank from which users can identify or make initial connections, acquire by transferring to their mini-bank, and access for use subsequently.

A sociocultural perspective on form-meaning connections, however, emphasizes the contextual variability of semantic meaning of utterances (Rommertveit, 1974) and the role of interaction in constructing meanings. According to Gee (1999) "meanings of words are not stable and general” (p.3) but "are associated with different 'situated' or 'customized' meanings in different contexts” (Gee, 2004, p.19). Drawing on Bakhtin's (1981, 1986) dialogic view of language use, Gee (1999, p.54) argues that "words have histories" in that our way of speech is shaped by the speech of people who came before us and in turn shapes the speech of people who come after us. Viewed from this perspective, the meaning of an utterance in any social encounter does not reside solely in the form, nor does it totally reside in the user's cognitive faculty, or even the immediate context alone, but reflects how interlocutors interpret and interact with different contexts of use and how they establish links between their existing repository of semiotic resources and new contexts emerging in the interactions. Gee (2004, p.19) illustrates how different situated meanings may be assembled by interlocutors with "coffee” as an example. The meaning of 'coffee' will take different forms if what follows the utterance "The coffee is spilled" is "Get a broom” rather than “Get a mop”, or vice versa.

Even though sociocultural researchers do not see language users as the original and sole meaning creator (Gee, 1999; Bloome \& Egan-Robertson, 2004), they emphasize their active role in the meaning-making processes. In comprehending a text, for example, learners bring to the task their previous experience of the world, including experience of other texts and contexts. Armed with such embodied and lived experience and based on how they construe the context, learners "assemble" 
Final Draft

meaning “on the spot” (Gee, 2004, p.19, italics in original). The role of the learners in the acquisition and use of form-meaning constructions is not only concerned with the cognitive ability of the learners to assimilate and reproduce as a result of the teachers' input, but also with how learners understand target language forms in relation to the body of knowledge they have accumulated over time through repeated participation in socially defined communication. This includes classroom instructional conversations with the teachers and other students, as well as extra-curricular interactions. The perspective of learning as situated discourse appropriation aligns with Hopper's (1998) idea of an emergent grammar. According to Hopper (1998, p.156), speakers "borrow heavily from their previous experiences of communication in similar circumstances, on similar topics, and with similar interlocutors.” The outcome of the appropriation may or may not match the L2 (second language) target anticipated by the teacher, but the causes for any unsuccessful meaning-making cannot be totally attributed to the learners’ negative L1 (first language) transfer or cognitive deficiencies. Rather, that lack of success can be seen as the product of the semiotic resources available, emerging and co-created by all interlocutors concerned in the context, and how the learners understand and recruit the resources according to their previous experiences.

Thus, all speech utterances must be interpreted and appropriated in the social contexts of their use. In their edited book explicating the role of text and context on language study, Kramsch and McConnell-Ginet (1992) identify this essential and active agency of learners:

"Learners themselves are to weave together texts and contexts to make meanings and to give power to words: they could no longer passively recognize a transcendental realm of pre-made units of meaning associated with pre-built texts but must begin actively to engage in discursive practices that create spoken and written texts and endow them with meanings. Linguistic form does not 
Final Draft

disappear but assumes importance as a socially shared communicative resource.” (p.6)

The need to acknowledge the important role of the learners in collaborative sense-making in grammar teaching has also been highlighted in Donato and Adair-Hauck (1992), who investigate the role of discourse in formal instruction. Drawing on Vygotsky's (1979) sociocultural views on cognitive growth, they propose a kind of discursive mechanism named "proleptic instruction” (p.83) an essential quality of which is the achievement of formal instruction through dialogue. Donato and Adair-Hauck argue that it is important to involve the child or novice in "the search for the problem solution rather than simply solving the problem and reporting the solution to the child” (1992, p.83). They believe that

“through proleptic utterances individuals are challenged to recreate each other's perspective on the topic and task at hand. Thus, both parties come to acquire relevant knowledge of the other's understanding of the problem and its solution.” (ibid:83-84)

In this paper, we further argue that the successful implementation of this knowledge co-construction process requires attempts to establish a shared contextual understanding of the issues and agendas among the interlocutors. All the above arguments and observations illuminating the sociocultural significance in FonF instruction strongly demand a corresponding awareness on the part of the teachers.

\section{Teacher Language Awareness (TLA) and FonF Instruction}

Traditionally, a teacher's language awareness refers to the teachers' knowledge about language (subject-matter knowledge), knowledge of language (language 
proficiency), and procedural knowledge of metalinguistic talk (Andrews, 1997, 2003). TLA is believed to have a significant impact on how teachers conduct grammar or form-focused instruction (Borg, 2003). The need to incorporate sociocultural perspectives in the knowledge base of language-aware teachers has recently been proposed by Andrews (2007). This arises from the awareness that the ability of the teachers to conduct effective metatalk in grammar instruction not only reflects what they know about the language, and whether they can use the language proficiently, but also the extent to which they can make their instructional discourse easily accessible to the learners. This involves the ability to understand challenges to understanding and performance from the perspective of the learners. This aspect of TLA focuses primarily on ways of handling errors made by students, and of guiding students to realize the different communicative impacts of choosing different formal options. Such an acknowledgment of the need to take learners into pedagogical consideration is an appropriate move towards enhancing teachers' awareness that learning is "socially constructed through both interpersonal and intrapersonal interactions" (Andrews, 1997, p.37; also see Lantolf, 2000). The scope of TLA thus covers not only expectations on the teachers' roles as effective language users and language analysts (Edge, 1988, cited in Andrews, 2007) but also effective mediators of language learning, which involves an awareness of "the challenges posed for the learners by the language content of pedagogic materials and tasks” (Andrews, 2007, p.175).

The need to factor in learner characteristics in pedagogical design is by no means a new discovery. In an FMCs approach to SLA, learner factors mainly deal with the L2 proficiency of the learners, and the extent to which the learners display L1 transfer when FMCs are not properly established (e.g. VanPatten et al., 2004). From a sociocultural perspective, learners' learning is believed to be affected by the linguistic and cultural resources students have accumulated over time, and which they turn to as 


\section{Final Draft}

part of the learning process, to make sense of the teachers' pedagogical input (see Canagarajah, 2000; Lin, 2000; Luk, 2005). While increased awareness of the role of learners in L2 learning has motivated teachers to be more tolerant of or receptive to learner errors, the general mentality among most teachers in the context we are studying remains error-phobic. In a highly competitive and exam-oriented community such as Hong Kong where teachers are charged with a tight school curriculum, most teachers are anxious to enable students to obtain as many right answers as possible within the limited class contact hours. Even though learner errors can be taken as evidence of mental functioning, they are seldom welcomed as evidence of achievements, and seldom capitalized on for knowledge building. When non-target-like student productions emerge, most teachers still tend to evaluate them negatively, and attribute such "errors" to the learners' low proficiency, L1 transfer, or poor attitude. In this paper, we argue that socioculturally-informed language awareness might enable teachers to be more alert to how learners' non-target-like FMC attempts might be discursively constructed and situated in the immediate and/or distant contexts that teachers play a part in constructing. We also intend to discuss how teachers with such awareness could act to expand the opportunities for learning by attempting to capitalize on students' non-target-like FMCs in constructing new knowledge.

While Andrews (2007) has made a timely call for TLA to incorporate sociocultural perspectives, not many data along this line are documented. The authors of this paper intend to contribute to this area by presenting and discussing in the following sections four naturally-occurring classroom episodes from an EFL classroom in Hong Kong.

\section{The Study}


Final Draft

The data presented in this paper came from a two-year classroom-based project ${ }^{1}$ to investigate how a group of Hong Kong EFL teachers (two primary and three secondary) conducted teaching of language form and language meaning. Theoretically, the project draws on concepts from two main areas, cognitive psychology and socio-cultural theory. Cognitive psychologists (e.g. Levelt, 1989; Skehan, 1998) see language processing as a type of skill processing, in which attention needs to be allocated to different aspects of the skill. Sociocultural theory in the Vygotskyan (Vygotsky, 1979, 1986) tradition (also see Lantolf, 2000), which is the key theory employed to interpret the data in this paper, emphasizes features of scaffolding manifested in teacher-student classroom interaction for the teaching and learning of new language.

\section{Method}

The wider project involves five teacher-researcher pairs conducting two phases of collaborative classroom-based action research (AR) plus one phase of pre-AR baseline data collection in which no teacher-researcher collaboration took place. Between each phase, there was an interval of about 6 months. Classroom observations and interviews were the two major data collection methods. A semi-structured, in-depth interview was conducted with each teacher before base-line data collection to explore the teachers' general perceptions of language teaching and classroom practices. In the two phases of collaborative action research, the teacher-researcher pairs conducted joint lesson-planning ${ }^{2}$ before the teachers conducted the research lessons (two lessons ranging from 45- 80 minutes each). All research lessons were observed, video-recorded and transcribed. Post-lesson interviews in the form of stimulated recall interviews (SRI) (see Gass \& Mackey, 2000) were conducted immediately after the lessons during which the teachers were asked to pause the 
Final Draft

videoed lessons whenever they wanted and explain the reasons behind their classroom practices in all the three phases. The SRIs were conducted by the teachers' researcher-partner mainly in Cantonese, the teachers' first language, with a lot of code-mixing in English. To collect feedback from students about what they thought they had learnt from the research lessons, four students of high and low English performance were identified by the project teachers to attend a highly structured individual interview ${ }^{3}$ as soon as possible after the lesson with a research assistant in the students' L1. The interview questions required them to identify what the teachers wanted them to learn through each specific teaching activity and what difficulties they had encountered in performing the tasks. The verbatim data of all teacher and student interviews were translated into English by a research assistant.

A micro-analysis of the classroom data organized looked at IRF (initiation-response-feedback) sequences, focusing on the interaction practices employed by the teachers to draw students' attention to language form and meaning, how the students responded and how the teachers provided feedback. Post-data-collection interviews were conducted with some teachers when specific instructional practices emerging from the transcripts of the classroom data had not been identified and addressed sufficiently in the SRI. These interviews were, however, conducted more than one year after the data collection period finished due to the amount of time required for one research assistant to transcribe all lessons from the five teachers. Fortunately, by presenting the transcripts to the teachers and playing relevant sections of the video, the researchers were able to obtain the teachers' insider perspectives on most of the FonF instructional practices.

\section{Participants and Data}

The data presented in this paper came from the classroom of a secondary teacher 
called Ronnie (a pseudonym), who volunteered to participate in this project with two of her colleagues, and whose researcher-partner was the second author of this paper ${ }^{4}$. Ronnie was in her late twenties and had 6-7 years of ELT experience when the project was conducted. She received a bachelor's degree from a prestigious university in Hong Kong majoring in English literature and linguistics, a Postgraduate Diploma in Education and a Master's degree in Education. Even though as an English major, Ronnie was not required to take the language proficiency test for English teachers in Hong Kong, she attempted all five papers and passed four of them (Speaking, Listening, Reading and Writing) with level 4, which is the second best level. In both the speaking and writing papers, an error identification and explanation task was included that assessed the teachers' grammatical knowledge and metalinguistic abilities. Over the last few years, over $60 \%$ of the test-takers failed these two tests (attaining below level 3). Being able to attain level 4 in these two papers reflects Ronnie’s above-average proficiency in English grammar among most Hong Kong teachers. However, Ronnie had obtained only level 3 for the fifth paper, Classroom Language. In this paper, teachers' ability to present teaching points, explain key concepts (the language of instruction), and their ability to elicit and provide feedback on students' responses (the language of interaction) are assessed in a real-life classroom. Classroom Language has always been the paper with the highest passing percentage ${ }^{5}$. Overall, Ronnie was rather confident in her knowledge of English, but she expressed the need to improve her teaching methodology.

The class Ronnie taught when the data were collected was a junior secondary class (equivalent to Grade 7 and Grade 8). According to Ronnie, even though the students' ability in English was not high, they were the best class in the year levels. It was evident from the lesson observations that most of the students were well-behaved and attentive even though they were not always actively responsive. 
Final Draft

Ronnie's case was chosen to be presented in this analysis mainly because of her strong belief in the essential role of learning formal properties in SLA. Unlike other project teachers who focused predominantly on teaching lexical expressions and text comprehension, Ronnie often had an explicit focus on grammar in her lessons. She explained that her strong beliefs in the role of grammar in language learning probably reflected her personal language learning experience. She graduated from a school where grammar learning was emphasized. Concerning the notions of FonF instruction and language awareness, Ronnie admitted that she had never heard of these terms.

Two sets of classroom data illustrating Ronnie’s teaching of both grammar and vocabulary will be presented in the next section. These data sets were selected because they support our contention that FonF instruction is problematic when teachers lack sufficient awareness of the challenges posed by the teaching content, and of the creative role of the learners in the meaning-making process. Our discussion of the classroom data will be supplemented by the background interview, the stimulated recall interviews, and the post-data-collection interview whenever appropriate. As no data relevant to the classroom episodes presented and discussed in this paper emerged in the student interviews, findings from student interviews will not be reported in this paper.

\section{Findings and Discussions}

In the background interview, Ronnie stated that language knowledge such as grammar rules and the meaning and pronunciation of words was indispensable and was the foundation of correct language use. She believed that her first priority should be to teach language form clearly, systematically and explicitly, and she would then "teach the meaning and function afterwards.” Ronnie’s pedagogical beliefs may explain why she often had an explicit focus on lexico-grammatical components in her 
Final Draft

lessons. In what follows, we will show how Ronnie conducted FonF instruction in different phases of the project.

\section{Data set 1 - Focusing on grammar}

Data set 1 comes from the pre-AR phase. The episodes show how Ronnie drew students' attention to verbs and time words that denote past tense. The lesson took place in November, the third month of the first school term that began in September of that year. It was a textbook-based general English lesson around the theme of shopping. At the beginning of the lesson, Ronnie reviewed several vocabulary items related to names of shops that could be found in a shopping mall and checked answers to some textbook tasks assigned as homework. The tasks were mainly comprehension exercises with multiple choice and short answer questions that covered vocabulary knowledge, factual understanding, reasoning and interpretation based on an email text. The email text with the subject title "My last shopping trip" is written by “Mark” to “Tony” and talks about a shopping trip to Hong Kong that Mark had made three days before returning home to Canada and writing the email. The email therefore contained many past tense verbs.

After checking answers to the comprehension exercises, Ronnie introduced past tense to the students. She first asked students to identify the tense used in the email, which most students were able to do accurately. Then, she told the students to underline "time words for past tense” (quoted from Ronnie’s verbal instructions). Underlining target language items is a popular strategy used by teachers to focus students' attention and it has been reported to be an input enhancement strategy (e.g. White, 1998). The introduction of the concept of "time words" probably reflects Ronnie's awareness that the notion of pastness in English could be conveyed through temporal lexical expressions (e.g. yesterday, before) as well as with bound and 


\section{Final Draft}

unbound morphemes (e.g. -ed, was) (VanPatten, Williams, \& Rott, 2004). However, after giving students a few minutes to do the underlining, Ronnie changed her verbal instructions from an elicitation for "time words" to "verbs in past tense”. Answers proffered by the students in response to Ronnie’s elicitation first for "time words” and then "verbs in the past” included “did”, “on Saturday” and “enjoyed”. Probably realizing that "on Saturday” is not a verb in past tense, Ronnie attempted to engage students in some metalinguistic discussion. She first asked students to say if they agreed that “on Saturday” was a "time word”. When nobody responded, Ronnie provided the following explanation:

When we say “on Saturday”, can we, you know, can we talk about "on Saturday” next week? On Saturday. Can I talk about on Saturday next week? Next Saturday? In fact, yes. But the problem is, we know that in this email, we know that we are talking about something happened already, okay, because we are talking about the shopping trip. All right. So it should be something finished already, so that’s why “on Saturday” can be a time word.

Ronnie’s explanation, though highly clumsy, reflects her basic understanding of the importance of context in interpreting the meanings of certain expressions. In the email, “on Saturday” refers to past time, but in another context, "on Saturday” may refer to future time. However, Ronnie did not act further to check and evaluate students' understanding of this important concept of context and meaning. She continued to elicit "other words that are time words" from the students. It should be noted that right before Episode 1 took place, Ronnie asked for "time words" rather than "time words for past tense": two terms and two concepts that are not identical. "Verbs in the past tense" clearly denotes the time reference whereas "time words" could be words that refer to time in any sense. From students' subsequent output described in the next paragraph, it seems that some students viewed the teacher's 
Final Draft

questions as elicitations of both "time words" in the general sense and "verbs in the past”.

Before we look at the episodes, it should be noted that apart from two occurrences of "on Saturday", "last” is the only potential "time word" found in the email text. The word "last” appears once in the email subject (My last shopping trip) and three times in the text. The first instance appears at the beginning of the third paragraph, “On Saturday, my last day: -(, I went to New Town Plaza with Uncle Jim.” The other two instances appear in the last paragraph - "Anyway, that was my last shopping trip (and my last adventure) in Hong Kong." "Last" is a "potential" time word because it has two possible meanings in this context: (1) "no more, being the only one remaining” or (2) “most recent, next before the present” (Cambridge Advanced Learner's Dictionary, 2003). Thus, strictly speaking, there are no unambiguous "time words for past tense" available in the text that are similar to temporal expressions such as "yesterday, before, ago” although most students would have been exposed to "last" in its meaning of "next before the present" since teachers always talk about what happened in the "last lesson" (meaning the most recent one) as a lead-in to the present one. The multi-layered meanings of the word "last" students' possible knowledge of one or more of these meanings were unfortunately not exploited by the teacher as will be shown in Episodes 1 and 2.

Episode 1 (Please refer to the Appendix for transcription conventions).

\begin{tabular}{|l|l|l|}
\hline 1 & $\mathbf{T}:$ & ... So in this passage, \\
\hline 2 & & can you find some OTHER words that are time words? \\
\hline 3 & & Any more? \\
\hline 4 & & Any more (.) time words. \\
\hline 5 & S1: & No. \\
\hline 6 & $\mathbf{T :}$ & No? No more? \\
\hline 7 & & (responding to another student's contribution) Sorry? \\
\hline
\end{tabular}




\begin{tabular}{|c|c|}
\hline 8 & (repeating a student's utterance that is inaudible on the tape) my last day. \\
\hline 9 & Some one say 'my last day’. \\
\hline 10 & Okay. I think, when we say 'last’, it actually means ‘最後” <the last one>. \\
\hline 11 & It doesn't mean '上一日' <yesterday>. \\
\hline 12 & $\begin{array}{l}\text { 唔係咁講, ‘上一日’點講啊? < It cannot be said this way. How do you say } \\
\text { 'yesterday’?> }\end{array}$ \\
\hline 13 & I would say, '上一日’ <yesterday>, yeah, we say ‘yesterday’. \\
\hline 14 & So this one no, \\
\hline 15 & but we know that, for the whole story, \\
\hline 16 & we know that on Saturday, this Saturday is last Saturday, \\
\hline 17 & So that's why we know that it's past tense. \\
\hline 18 & Very good. \\
\hline 19 & I won't go through all of them with you. \\
\hline 20 & At least I know that you have some concepts about past tense. \\
\hline 21 & Before we move to tenses, I give you a three-minute break. \\
\hline
\end{tabular}

As discussed above, "last" does not denote the past time meaning of "the day before today" in the linguistic and semantic context of "my last day", as indicated by Ronnie (lines 10-13). In this sense, Ronnie seems to be in possession of the required subject matter knowledge to appreciate the multiple and probabilistic nature of form-meaning connections in the sense that one form may encode several meanings (see Ellis, 2004). In fact, her effort to explain these multiple meanings in Cantonese, the students' first language, probably reflects her understanding of the students' and/or her own difficulty with English-language explanations of this complexity. There is evidence in Episode 1 that Ronnie was not able to present a clear concept of the multiple meanings and uses of "last" through effective metalinguistic talk. For example, on line 10, by using a "when-clause" to show co-occurring actions ("When we say 'last', it actually means ‘最後’ < the last one>.”), and “actually” as an adverb implying high certainty, Ronnie seems to have problematically presented one of the several meanings of "last" as if it were the only accurate meaning. Even though her 
Final Draft

negative evaluative comment on line 14 ("so this one no") shows an attempt to contextualize the meaning of "last" with the determiner "this", she did not explain further what other clues support the interpretation that "last" does not denote pat tense in this context.

Another observation from Ronnie’s virtually monologic explanation concerns her self-initiated reference to "on Saturday” (line 17). It was initiated probably because “on Saturday” was earlier proposed by another student as an example of "time words for past tense” that she had accepted. However, Ronnie's explanation is not very clear because by saying “this Saturday is last Saturday so that's why we know that it's past tense (lines 17-18, italics added)", she seemed to be associating "last” with past tense. Without any attempts to check student understanding, Ronnie missed an opportunity to ensure that most students had understood why "last” is accepted as referring to past tense in "last Saturday” but not in "my last day".

Ronnie's wordy explanation also evidenced her adoption of a teacher-directed transmission style of FonF instruction. She did not give the turn formally to any student to reply after her Cantonese initiation (line 12, <How do you say 'yesterday'?) but provided the answer straight away by herself (line 13). This elicitation practice is not uncommon in classroom teaching in Hong Kong. It may be due to time constraint or a general belief that students would not be able to, or willing to, answer, or it may simply be a rhetorical question as the answer is obviously well-known to all students. The key issue is that she did not attempt to initiate other questions to guide students to see the differences between "my last day" and "yesterday" but provided the explanations by herself. Such a teacher-dominated practice greatly reduces the role of the learners in "collaborative sense-making” with the teacher as suggested by Donato and Adair-Hauck (1992), and in turn, reduces opportunities for learning.

Episode 2 appeared after the 3-minute break mentioned in Episode 1. 


\section{Episode 2}

\begin{tabular}{|c|c|c|}
\hline 1 & T: & All right. We talk about time, the time that something happened. \\
\hline 2 & & So very clear. \\
\hline 3 & & Can you give me some other words? \\
\hline 4 & & That means, when we saw it, when we see it, we know it is past tense. \\
\hline 5 & & Here I give an example like time words, (writes 'time words' on the blackboard) \\
\hline 6 & & $\begin{array}{l}\text { I give you the words like eh (.) 'this morning' (writes 'this morning' on the } \\
\text { blackboard). }\end{array}$ \\
\hline 7 & & So if I have 'this morning', we can also have 'this afternoon'. \\
\hline 8 & & So then we know that something happened. \\
\hline 9 & & $\begin{array}{l}\text { Okay. And then on the board, I've also given you the word 'yesterday'. (writes } \\
\text { 'yesterday' on the blackboard.) }\end{array}$ \\
\hline 10 & & All right. Can you give me some more other time words? \\
\hline 11 & & Yes? (as a gesture of inviting a student who bids for the turn to speak). \\
\hline 12 & S2: & Last. \\
\hline 13 & T: & Very good. Last. \\
\hline 14 & & How to spell it? \\
\hline 15 & S2: & L-A-S-T \\
\hline 16 & T: & (writes 'last' on the blackboard.) What would you say? \\
\hline 17 & & Last? (rising tone at the end, inviting students to complete) \\
\hline 18 & S3: & Year. \\
\hline 19 & T: & $\begin{array}{l}\text { For example, when you say last year, last... (high level tone inviting students to } \\
\text { complete) }\end{array}$ \\
\hline 20 & S4: & Last day. \\
\hline 21 & T: & Do we say 'last day’? \\
\hline 22 & & (probably picking up a student’s utterance) Last month. All right. \\
\hline 23 & & What else? Last week, last ...(high level tone inviting students to complete) \\
\hline 24 & S5: & Minutes. \\
\hline 25 & T: & Minute, very good. \\
\hline 26 & & Last minute, last minute. \\
\hline 27 & & Okay what else? \\
\hline 28 & S6: & Last second. \\
\hline 29 & T: & (T and Ss laugh) Thank you. \\
\hline 30 & & Can we say last music day? \\
\hline 31 & S7: & Yes. \\
\hline
\end{tabular}




\begin{tabular}{|l|l|l|}
\hline 32 & T: & Yes or no? \\
\hline 33 & S8: & Yes. \\
\hline 34 & T: & Can we say “last sports day?” \\
\hline 35 & S9: & Yes. \\
\hline 36 & T: & Yes, okay, very good. \\
\hline 37 & & So last minute, last time. All right. \\
\hline
\end{tabular}

Episode 2 is related to Episode 1 in the sense that a major part of the teacher-student interaction is around "last", a candidate answer put forward once again by a student in response to the teacher's elicitation for "time words". What is interesting about Episode 2 is the teacher's acceptance of "last” as a "time word", a phenomenon that seems contradictory to what happened in Episode 1. Not only does the teacher accept "last” as a time word, she also spends a series of turns to elicit more temporal expressions beginning with "last”. This intriguing change in pedagogical practice may be a result of Ronnie's decision to remove any reference to a specific context. This seems evident in her provision of examples of time words ("this morning, this afternoon, yesterday”) that do not appear in the email text. Such a removal of specific contextual reference to the email text made it possible and necessary for students to draw on resources from other texts and contexts. However, while temporal expressions such as "this morning” and “yesterday” usually carry a generic meaning of referring to past time, the time reference for expressions such as “this afternoon” seems more contextually variable. Without a shared text and context, the semantic reference of "this afternoon" would be difficult to determine. The manner in which Ronnie responds to "last day", "last music day" and "last sports day" was also unclear. On line 17, Ronnie queries the expression "last day” by asking "Do we say last day?”. However, no attempt was made to obtain an explicit response from the students, nor did she herself attempt to explain the acceptability of "last day" as 


\section{Final Draft}

compared to other expressions such as "the last day" and “yesterday”. The teacher's positive evaluation on "last sports day” (“yes, okay, very good”, line 36) further confounded the problem because some students might find it very difficult to decide whether "last day”, "last music day”, and "last sports day” are all illustrating the same indexical meaning for the word "last", and whether they are all acceptable, and in what contexts.

In the SRI, Ronnie only made one comment concerning her teaching of past tense towards the end of the interview. "Instead of teaching the rules of simple past tense," she told the second author, "I let the students understand the content first and try to find the use of it [past tense] in the passage. I also hope that they could understand the use of simple past tense in the context of 'the last shopping trip'." Ronnie, however, did not mention anything related to the double-layered meanings of the adjective "last". When we raised this point in the post-data-collection interview ${ }^{7}$ Ronnie told us that she knew the word "last" had multiple meanings, but she only planned to concentrate on past meaning in the research lesson. Therefore, when she elicited "time words", she was having "time words for past tense" in mind. She acknowledged that some students might feel confused with her instruction as shown in the transcripts.

\section{Data set 2 - Focusing on lexical expressions}

Data set 2 comes from the first lesson in the first collaborative AR Phase, which took place towards the end of the second school term. In the joint planning meeting, Ronnie expressed her ideas to design a lesson to teach students "useful words for writing cooking instructions such as 'stir', 'mince', and the difference between 'chop up' and 'slice'” through a PowerPoint presentation with pictures showing how Ronnie made her favourite dish. The second author and Ronnie explored in the meeting 


\section{Final Draft}

alternatives to enable students to learn these words through self-discovery rather than listening to the teacher's presentation. They also talked about whether the students should be engaged in live cooking during the lesson or asked to videotape their cooking process at home and play the video in class. Finally, it was decided that after Ronnie's PowerPoint presentation, students had to form groups and practice using the acquired vocabulary items and sentence patterns (e.g. imperative structures) to give cooking instructions and make real salads in class. The following two episodes show what happened when Ronnie attempted to present the verb "mince" and the noun "mixture” during the PowerPoint presentation phase.

\section{Episode 3}

The following discussion took place after Ronnie showed a slide with a photo of a piece of meat and the expression "Mince the beef” below the photo.

\begin{tabular}{|c|c|c|}
\hline 1 & T: & You think it is beef, okay, because the colour looks dark. \\
\hline 2 & & All right. Not meat, but beef. \\
\hline 3 & & $\begin{array}{l}\text { So you can see the pattern like this. (miming the action of chopping } \\
\text { things.) }\end{array}$ \\
\hline 4 & & Okay. So what is it? \\
\hline 5 & & Mince the beef. (showed the words on the slide.) \\
\hline 6 & & What is ‘mince’? (a student said something.) \\
\hline 7 & & $\begin{array}{l}\text { Oh, you know it very well in Cantonese. In Cantonese, } \\
\text { dirtdirtdirtdirtdirt... (miming the action of chopping things and } \\
\text { making the sounds) }\end{array}$ \\
\hline 8 & S1 & 剁 <mincing by rapid chopping> \\
\hline 9 & T: & No, no, no. \\
\hline 10 & S2 & 免治 <the Cantonese term for ' minced’> \\
\hline 11 & T: & Yes. Good. Okay, louder, please. \\
\hline 12 & S2: & 免治牛肉 <minced beef $>$ \\
\hline 13 & T: & 免治牛肉. Very good. \\
\hline 14 & & $\begin{array}{l}\text { In fact, 免治 }<\text { Cantonese translation for 'minced'> is from, is from } \\
\text { English. }\end{array}$ \\
\hline
\end{tabular}




\begin{tabular}{|l|l|l|}
\hline 15 & & Just like our tie, 領帶 <tie>, tie is actually from English. \\
\hline 16 & & So you know this word, right. \\
\hline 17 & & Try to say it. One, two, three. \\
\hline 18 & Ss\&T: & (reading the caption of the slide) Mince the beef. \\
\hline 19 & T: & This is a verb. Okay. 'Mince' is a verb. \\
\hline
\end{tabular}

In the SRI, Ronnie explained why she “deliberately” encouraged students to respond in Cantonese to her elicitation "What is mince?”. “On the one hand”, she said, "I wanted to tell them that many Chinese words are derived from the pronunciation of English words, such as ‘免治' from 'minced'. On the other hand, they might be able to remember the pronunciation of 'minced' from that of the Chinese translation “免治””. Ronnie’s attempt to draw upon students' local language resources seems to signal her awareness of the need to make connections between the second language and the students' first. However, her negative evaluation of the Cantonese word “剁” < to mince meat by hand> proposed by S1 on line 8 shows her focus on a single right answer, that is “免治”. Ronnie’s strictly negative responses with three utterances of "no" on line 9 are problematic as a lot of Chinese would make minced meat through this action. We should note that before S1 proposed “衬”, Ronnie was miming exactly the action of “朵” (line 7). Therefore, even though the Chinese concept of “剁” may not be totally the same as the English concept of “mince”, evaluating it negatively dismisses students' embodied experience of how different languages may represent everyday concepts differently. Besides, the Chinese translation “免治” $<$ minced $>$ (pronounced as $\left[\min ^{3} \mathrm{dzi}^{6}\right]$ in Cantonese) is usually used as an adjective before the noun “牛肉” < beef> in Cantonese whereas “mince” as a verb shares the same word class as “朵””. Therefore, accepting “mince” as meaning “免治” <minced> may confuse students’ established concepts of parts of speech in both languages. When Ronnie introduced “免治牛肉” “"minced beef”, a term which 


\section{Final Draft}

did not appear on her PowerPoint slides), she should have highlighted the 'ed' ending of the word used as an adjective before a noun and prevented students from thinking that "mince" is used with the same form in "minced beef" (as the ending /t/ sound in "minced" is usually not distinct in connected speech and many students might have missed it) and "mince the beef" (which may sound very similar to "minced beef" in quick speech). In the post-data-collection interview, Ronnie acknowledged the problem with her negative evaluation of “剁” and agreed she should have accepted it. As for the "mince" and "minced" distinction, Ronnie admitted that she had overlooked the potential confusion.

\section{Episode 4}

Episode 4 took place about 10 minutes after Episode 3 and Ronnie was coming towards the end of her PowerPoint slides. On the second to last slide, there was a picture showing a big pot of what seemed to me to be raw egg yolk with a stirrer being dipped into it. Underneath the picture, a sentence read: Stir the egg yolks with the mixture. Immediately before Episode 4, a student proposed "stir" in response to Ronnie’s action of stir-frying.

\begin{tabular}{|c|c|c|}
\hline 1 & T: & Stir. Yes, in fact, we will not stir-fry egg yolk, not stir-fry. \\
\hline 2 & & But we use the word (.) stir. \\
\hline 3 & & Very good, stir means 搞. Here, we stir the egg yolks- \\
\hline 4 & S1: & 蛋漿 < a thick liquid of egg yolk> \\
\hline 5 & T: & 蛋漿 < a thick liquid of egg yolk>. Yeah, with the mixture. \\
\hline 6 & & Can you make a guess. \\
\hline 7 & & $\begin{array}{l}\text { What is the meaning of 'mixture'? (writes 'mixture' on the } \\
\text { blackboard.) }\end{array}$ \\
\hline 8 & S2: & 搞蛋器 <an egg stirrer> \\
\hline 9 & T: & A good try. \\
\hline 10 & & You think this is 搞蛋器 <an egg stirrer>. No, no, no. \\
\hline 11 & & This is the mixture. (points to the egg yolk on the slide.) \\
\hline
\end{tabular}




\begin{tabular}{|c|c|c|}
\hline 12 & & $\begin{array}{l}\text { Oh, I show you the picture. (showed the last slide with a bowl of } \\
\text { assorted fruits and the sentence Mix the pear with the strawberry } \\
\text { underneath it) }\end{array}$ \\
\hline 13 & & This is, this is mixture. \\
\hline 14 & S3: & 搞拌自 < a blending bowl> \\
\hline 15 & T: & No. 唔係搞拌萖 <not a blending bowl> \\
\hline 16 & S4: & 裡面眬材料 < the materials inside $>$ \\
\hline 17 & T: & Very good. Remember, we mix them together. \\
\hline 18 & & We mix, we mix the apple, we mix the banana together. \\
\hline 19 & & And then afterwards, we call it a mixture. \\
\hline 20 & & Do you know what I mean? \\
\hline 21 & & $\begin{array}{l}\text { When you mix them together, it is mixture already. 已經混合咗一齊 } \\
\text { 啦 < already mixed together>. }\end{array}$ \\
\hline 22 & & So mixture. Yes, good. \\
\hline 23 & & $\begin{array}{l}\text { Read after me. (returned to the slide with the egg yolk.) Stir the egg } \\
\text { yolks with the mixture. }\end{array}$ \\
\hline
\end{tabular}

It seems evident from Episode 4 that most students in this class did not know or were not sure about the meaning of “mixture”. However, we can note S2's and S3's attempts, even though futile, to establish the form-meaning connection of "mixture" by employing the semiotic resources (the photos and captions) provided in the immediate context through the PowerPoint slides prepared by the teacher. However, these resources were potentially misleading. The preposition "with” in the caption Stir the egg yolks with the mixture (underlining in the original) appeared underneath a photo that shows a stir in a pot of raw egg yolk. S2 might well have thought, therefore, that "mixture" was the tool used to stir the egg yolk because the meaning of "with" in the pattern "to stir something with something" can either mean "using [an instrument]” or “and” [in this case, 'stir together']. S3's proposed answer (“a blending bowl”, line 14) ostensibly also reflected a similar logic in his situated construction of meaning based on the egg yolk photo and the photo with a big bowl of mixed fruits. The grammatical position of "mixture" in the egg yolk sentence enables him to 
understand "mixture" as a noun denoting something that people use to do or hold the mixed stuff. Thus, the proposed answers from S2 and S3 reflected their on-the-spot attempts to construct FMCs by making associations between the semiotic resources available in the context and their previous meaning-making experiences in English. Ronnie makes an initial positive appraisal of S2's attempt (line 9), but her subsequent repeated "Nos” to S2 and S3 do not take into consideration the students' perspectives or recognize the potential problem of her instructional discourse and other forms of semiotic input on students' learning.

In the SRI, Ronnie did not make any comments on the responses proposed by S2 and S3. In response to the second author's query about teaching the preposition “with” but not other prepositions, Ronnie then explained her intention to teach "with" because she thought it was important as "the word 'mix' must be used with it." In the post-data-collection interview when Ronnie's attention was drawn to the picture with the caption Stir the egg yolks with the mixture and S2's proposed answer in the transcriptions, Ronnie was able to explain why S2 had made that suggestion "because he was thinking of some tools to do the stirring”. When we suggested that the caption should be more accurately expressed as Stir the egg yolk into the mixture, Ronnie said that it was not what she intended because her focus was on "mixture" and the action of "mixing something with something else into a mixture through the action of stirring.” It seems that Ronnie was thinking of “egg yolk” as one object, and "mixture" as another object (Ronnie suggested that this could be flour and butter) to be mixed together through stirring. She wanted to teach different action verbs such as "mix" and "stir" which would be useful in the salad-making activity. She admitted that the photo did not express her ideas clearly.

\section{Implications}


Final Draft

The naturally-occurring FonF instructional episodes presented above reveal how form-meaning connections of certain lexico-grammatical items are situationally constructed by students through drawing on semiotic resources across texts and contexts, as well as how a lack of such awareness on the part of the teacher have reduced the opportunities for students to claim more ownership of their learning. Even though the teacher possessed basic subject matter knowledge, she seemed to be lacking awareness of the dialogic nature of texts and contexts, and the language learners as active meaning-makers in a sociocultural paradigm. Without such an awareness, the teacher may miss valuable opportunities to scaffold students' language learning effectively through engaging them in an active dialogic inquiry and exploration of contextualized form-meaning connections. This points to the need to reconceptualize form-meaning connections in FonF instruction from a sociocultural perspective. We argue that this should constitute an important part of the knowledge base of a teacher's language awareness. In the following paragraphs, we discuss three dimensions along which sociocultural perspectives of FonF instruction could be incorporated into TLA. We also draw pedagogical implications from the dimensions.

The first dimension concerns the need to acknowledge the role of intertextual and intercontextual resources in the meaning-making processes. As Lemke (1985, p.275) argues, no text or occasion of discourse is ever understood "in isolation from the wider systems of intertextual meaning relations in the community.” The responses provided by the students in the four episodes indicated the possibility that resources to construct form-meaning connections in a particular text and context may come from other texts and contexts available in or exterior to the classroom situation. These texts and contexts may include (1) those provided in the commercially produced textbooks; (2) those provided as part of the teacher's teaching materials (these are often multimodal such as photos, sound tracks, and captions on PowerPoint slides, 


\section{Final Draft}

worksheets and/or notes written on the board, etc.); (3) the teacher's impromptu verbal instructions; (4) the teacher's body gestures; and, most importantly, (5) the texts and contexts students have conjured up in their mind based on their previous experiences of how languages are used in their everyday lifeworlds. It must be emphasized that the last point is by no means a new finding. Researching in similar contexts in Hong Kong, Tsui (2004a) reported that the students she had observed were found to have "brought in their own experience to assign meanings to the object of learning” (p.146) which might not be congruent to the teachers' tacit assumptions. To scaffold students' learning effectively, it is essential for teachers to develop an awareness both of what their students bring to the instructional context, and of the assumptions embedded in their own discourses.

In this regard, rather than simply focusing on the text(s) and context(s) they have in mind when interpreting students' utterances, teachers should attempt to accomplish an intersubjective understanding with the students about what texts and contexts they might be recruiting when those students construct form-meaning connections that seem to be different from theirs. The notion of intersubjectivity (see Thorne, 2000) suggests that shared cognition and consensus is essential in the shaping of our ideas and relations. This understanding is in line with what Marton and Tsui (2004) have proposed as the "shared space of learning" which denotes a shared common ground, or intersubjective understanding, in relation to "the object of learning” (Tsui, 2004b, p.165). Tsui (2004a) argues that teachers could widen the space of learning shared with the students through structuring and re-structuring their instructional discourse in such a way that students are engaged in negotiations of meaning and are enabled to discern "critical features of the object of learning” (Tsui, 2004a, p.137) and their “contextual variation” (ibid, p.139). For example, instead of dismissing a student’s non-target-like answer as wrong, the teacher in Tsui (2004a) showed understanding of 


\section{Final Draft}

the student's way of thinking and made an effort to guide the student to produce a correct linguistic representation of her knowledge. The instructional discourse enacted by those more effective teachers displays features of scaffolding (see Gibbons, 2002; Wood, Bruner \& Ross, 1976), a sociocultural concept of learning that has been used widely and broadly to refer to how teachers (or experts) may guide students' (or novices') learning through verbal interaction (see the recent discussion in Forman, 2008).

The four classroom episodes presented in this paper, however, show that the teacher had narrowed the space of learning by not attempting to scaffold students' form-meaning constructions on the understanding the students used to produce their answers. To widen the space, the teacher should seek to stand on a common ground with the students in order to understand their perspectives, and gradually engage them in a genuine negotiation of meaning (see Donato \& Adair-Hauck's (1992) idea of “proleptic instruction” in an earlier section) to enable them to discern the contextual variation of the critical features of the form in focus. For example, whether "last" means "the only one remaining" or "the most recent one" could be considered from a variety of clues in the linguistic and semantic contexts such as its position and function in a sentence, the availability of a determiner, and other temporal expressions in the text. In the sequence analyzed, Ronnie could have compared and contrasted the meanings of "(the) last day”, "last sports/music day”, "my last day” by engaging students in a joint exploration of typical contexts where these expressions may appear. In Episodes 3 and 4, rather than dismissing student responses as wrong, Ronnie could have attempted to deconstruct the students' form-meaning connection processes from their perspectives. For example, in Episode 3, the semantic differences between the Cantonese concept of “剁” <mincing by rapid chopping> and “mince”, and the grammatical functions of "mince" and "minced" could have been discussed. In 
Final Draft

Episode 4, the student's ability to discern the neighboring preposition in the process of establishing the critical features of the word "mixture", though inaccurate, could have been acknowledged and capitalized on. Whether these collaborative inquiries could emerge hinges on an intersubjective understanding of what heuristic resources students might be drawing on in meaning-making.

The third dimension of socioculturally-informed TLA concerns the need to revisit the notion of "communicative competence" that has a direct impact on teachers' language awareness. A teacher's subject matter knowledge and language proficiency were proposed by Andrews (2003) to be key components of a language teacher's knowledge base, and it is natural for many people to think that teachers possessing these two aspects of language awareness are communicatively competent. Data from the observed lessons reveal that a teacher's language knowledge base should also include the awareness concerning the dynamic and contextually variant processes learners may go through in making meaning out of form, and how these processes may be different from those of the teachers.

Kramsch (2006) redefines communicative competence by arguing that communication involves understanding others and "to understand others, we have to understand what they remember from the past, what they imagine and project onto the future, and how they position themselves in the present” (p.251). Such an ability demands not just knowledge of vocabulary items or communication strategies, but “symbolic forms” that are "embodied experiences, emotional resonances, and moral imaginings” (Kramsch, 2006, p.251). Kramsch calls such an ability "symbolic competence” (as distinct from communicative competence) which on the one hand, acknowledges the importance of "form" as meaning representations, and on the other hand, calls for the need to take into consideration the complex sociocultural history of the persons. An effective production and exchange of symbolic goods in the process 
of communication requires the ability to understand the textual and contextual histories of the utterances delivered by the particular interlocutors.

A language teacher's symbolic competence in Kramsch’s (2006) configuration features most prominently in everyday classroom interaction. As mentioned in Section 4, Ronnie had obtained above-average results in the Language Proficiency Assessment tests in speaking and writing papers that included identification and metalinguistic explanation of errors, whereas only an average level was attained in classroom language which included the assessment of the language of instruction and the language of interaction in real classroom contexts. The instructional discourse of Ronnie as revealed in the four episodes may throw some light on her inability to obtain a higher score for classroom language. As discussed before, Ronnie’s FonF instruction was teacher-dominant and characterized by rhetorical questions that did not demand genuine answers, and/or test questions that demanded answers that were defined as either right or wrong. These patterns are often found in the default IRF pattern and have been criticized for reducing the opportunities for students to offer original information and opinions, and therefore, being non-conducive to promoting student participation (see for example, Gamoran \& Nystrand, 1991; Lemke, 1990; Wood, 1992). It was revealed in the post-data-collection interview that Ronnie was not focused on these issues, prioritizing instead the transmission of the teaching points she had pre-determined (e.g. verbs that denote past tense). Ronnie's case shows that even though a teacher may have obtained full qualifications and experience to serve as an English teacher, s/he may still display systemic conceptual and awareness blind spots about the sociocultural nature of the meaning-making processes. The essential role of text and context, and the learners in mapping form and meaning makes it imperative for teachers to re-conceptualize their dominant and "expert" role in the zone of proximal development proposed by Vygotsky (1979) as constituting more 
Final Draft

than a knowledge possessor, knowledge giver, or a learning evaluator, but as socioculturally aware interlocutors and knowledge mediator sensitive to what the learners might have brought to the learning environments.

\section{Limitations of the study}

Our discussion of the classroom episodes would have been more revealing if perspectives pertaining to the specific episodes could have been obtained from the students and teachers in a timely fashion. Due to time constraints, we could not replay the whole 80-minute lessons during the $\mathrm{SRI}^{8}$, and the discussions were around issues that Ronnie identified. Even though it was agreed by the project team that both the researchers and the teachers could stop the video, the second author of this paper seldom paused the tape in order to give more autonomy to Ronnie to decide what episodes she would select.

The sociocultural issues on FonF instruction discussed in this paper were not mentioned in the two collaborative planning meetings because of a different focus of interest of the second author ${ }^{9}$, who put more emphasis on teaching methodologies such as task design and task sequence. This was an area identified by Ronnie to be the priority focus in her action research ${ }^{10}$ and helps to explain her focus on formal outcomes rather than negotiation of meaning.

The issues raised in this paper were not discussed with Ronnie throughout the data collection period because it had taken the research assistant more than a year's time to finish transcribing all the lesson and interview data from five cases. By the time the issues discussed in this paper were identified, it was more than a year after the project had completed. Besides, as a novice researcher working with a teacher as experienced and well-qualified as herself, the second author admitted that she did not feel comfortable to bring up these language-related issues to Ronnie for fear that she 
Final Draft

might feel offended and challenged. To what extent such intriguing power-relationship between the researcher and the teacher is worth further investigation $^{11}$ (see discussion in McGee, 2008).

\section{Conclusion}

In this paper, we have discussed why there is a need for teachers to incorporate sociocultural perspectives on FonF instruction as part of their language awareness knowledge base. Through analyzing four naturally-occurring episodes from a Hong Kong EFL classroom, we revealed how the teacher's failure to establish intersubjective understanding of the different texts and contexts involved in the learners' form-meaning construction processes resulted in a less-than-optimal instructional discourse. To achieve effective FonF instruction, teachers should be more sensitive to the dialogic nature of students' meaning-making practices, and draw on mutually engaging textual and contextual resources in the discursive construction of form and meaning.

The findings reveal the importance of incorporating sociocultural perspectives into TLA. As pointed out by Kerr (1993, cited in Andrews, 2007, p.184), language awareness activity has "typically focused on the transmission of knowledge about language rather than on fostering an awareness of implications for the learner or the teaching/learning process.” The data and the discussion presented in this paper call for the need to develop in language teachers not just knowledge of FonF teaching methodologies, or knowledge of the language system as a system of discrete linguistic items, rules, and codified contexts of use, but also knowledge of how language users might construct meaning out of form as a dialogic and situational activity based on own previous experiences, and resources available in the immediate and distant texts and contexts. The latter type of awareness, as the case of Ronnie shows, could be 
Final Draft

more effectively discerned, developed, and evaluated in the classroom contexts through analyzing the instructional discourse of the teachers.

\section{References:}

Andrews, S. (1997) Metalinguistic knowledge and teacher explanation. Language Awareness, 6, 147-61.

Andrews, S. (2003) Teacher language awareness and the professional knowledge base of the L2 teacher. Language Awareness, 12(2), 81-95.

Andrews, S. (2007) Teacher language awareness. Cambridge: Cambridge University Press.

Bakhtin, M. M. (1981) The Dialogic imagination: Four essays by M. M. Bakhtin (Emerson, Caryl Holquist, Michael, Trans.). Austin: Univesity of Texas Press.

Bakhtin, M. M. (1986). Speech genres and other late essays (McGee, V.W., Trans.). Austin: University of Texas Press.

Borg, S. (2003). Teacher cognition in grammar teaching: A literature review. Language Awareness, 12(2), 96-108.

Bloome, D., \& Egan-Robertson, A. (2004). The social construction of intertextuality in classroom reading and writing lessons. In N. Shuart-Faris, \& D. Bloome (Eds.). Uses of intertextuality in classroom and educational research (pp.17-64). Connecticut: Information Age Publishing.

Cambridge Advanced Learner’s Dictionary (2003). Cambridge: Cambridge University Press.

Canagarajah, A. S. (2000). Negotiating ideologies through English: Strategies from periphery. In T. Ricento (Ed.). Ideology, politics and language policies (pp.121-132). Amsterdam/Philadelphia: John Benjamins.

Canale, M. \& Swain, M. (1980). Theoretical bases of communicative approaches to 
Final Draft

language teaching and testing. Applied Linguistics 1, 1-47.

Donato, R. \& Adair-Hauck, B. (1992). Discourse perspectives on formal instruction. Language Awareness, 1(2), 73-89.

Ellis, N. C. (2004) The process of second language acquisition. In B. VanPatten, J. Williams, S. Scott, \& M. Overstreet (Eds.) Form-meaning connections in second language acquisition (pp.49-76). Mahwah, New Jersey: Lawrence Erlbaum Associates, Publishers.

Forman, R. (2008). Using notions of scaffolding and intertextuality to understand the bilingual teaching of English in Thailand. Linguistics and Education, 19, 319-32.

Gamoron, A. \& Nystrand, M. (1991). Background and instructional effects on achievement in eighth-grade English and Social Studies. Journal of Research on Adolescence, 1.3, 277-300.

Gass, S.M. \& Mackey, A. (2000). Stimulated recall methodology in second language research. Mahwah, NJ.: Lawrence Erlbaum.

Gee, J. P. (1999). An introduction to discourse analysis : Theory and method._London ; New York : Routledge.

Gee, J.P. (2004). Learning language as a matter of learning social languages within discourses. In M.R. Hawkins (ed.). Language learning and teacher education: A sociocultural approach (pp. 13-31). Clevedon; Buffalo: Multilingual Matters.

Gibbons, P. (2002). Scaffolding language, scaffolding learning: Teaching second language learners in the mainstream classroom. Portsmouth, NH: Heinemann.

Hopper, P. (1998). Emergent grammar. In M. Tomasello (Ed.), The new psychology of language, (pp. 155-175). Mahwah, NJ: Lawrence Erlbaum Associates.

Hymes, D. (1972). On communicative competence. In J.B. Pride and J. Ho,mes (Eds.), Sociolinguistics. Harmondsworth: Penguin.

Kerr, P. (1993). Language training on pre-service cources for native speakers. Modern 
Final Draft

English Teacher, 2(4), 40-3.

Kramsch, C. (2006). From communicative competence to symbolic competence. The Modern Language Journal, 90, 249-252.

Kramsch, C., \& McConnell-Ginet, S. (1992). (Con)textual knowledge in language education. In C. Kramsch \& S. McConnell-Ginet (Eds.), Text and context: cross-disciplinary perspectives on language study (pp.3-25). Toronto:D.C. Heath and Company.

Lantolf, J.P. (2000). Introducing sociocultural theory. In J.P. Lantolf (Ed.), Sociocultural theory and second language learning (pp. 1-26). Oxford: Oxford University Press.

Lemke, J. (1985). Ideology, intertextually, and the notion of register. In J.D. Benson \& W.S. Greaves (Eds.), Systemic perspectives on discourse, Vol. 1. Selected papers from the $9^{\text {th }}$ International Systemic Workshop (pp.275-294). Norwood, NJ: Ablex..

Lemke, J. (1990). Talking science: Language, learning and values. Norwood, NJ: Ablex.

Levelt, W.J.M. (1989). Speaking: From intention to articulation. Cambridge, MA: MIT Press.

Lin, A. M. Y. (2000). Lively children trapped in an island of disadvantage: verbal play of Cantonese working-class schoolboys in Hong Kong. International Journal of Sociology and Language, 143, 63-83.

Luk, J. C. M. (2005). Voicing the "self" through an "other" language: Exploring communicative language teaching for global communication. In S. Canagarajah (Ed.), Reclaiming the local in language policy and practice (pp. 247-267). Mahwah, New Jersey: Lawrence Erlbaum.

Marton, F., \& Tsui, A.B.M. (2004). Classroom discourse and the space of learning. Mahwah, New Jersey: Lawrence Erlbaum Associates, Publishers.

McGee, A. (2008). Critical reflections of action research used for professional 
Final Draft

development in a Middle Eastern Gulf State. Educational Action Research, 16(2), 235-50.

Rommetveit, R. (1974). On message structure: A framework for the study of language and communication. New York : John Wiley \& Sons.

Skehan, P. (1998). A cognitive approach to language learning. Oxford: Oxford University Press.

Thorne, S.L. (2000). Second language acquisition theory and the truth(s) about relativity. In J. P. Lantolf (Ed.), Sociocultural theory and second language learning (pp. 133-154). Oxford: Oxford University Press.

Tsui, A.B.M. (2004a). The semantic enrichment of the space of learning. In F. Marton, \& A.B.M. Tsui (Eds.), Classroom discourse and the space of learning (pp.139-164). Mahwah, New Jersey: Lawrence Erlbaum Associates, Publishers.

Tsui, A.B.M. (2004b). The shared space of learning. In F. Marton, \& A.B.M. Tsui (Eds.), Classroom discourse and the space of learning (pp.165-186). Mahwah, New Jersey: Lawrence Erlbaum Associates, Publishers.

VanPatten, B., Williams, J., \& Rott (2004). Form-meaning connections in second language acquisition. In B. VanPatten, J. Williams, S. Scott, \& M. Overstreet (Eds.), pp.1-26.

VanPatten, B., Williams, J., Rott, S., \& Overstreet, M. (Eds.) (2004). Form-meaning connections in second language acquisition. Mahwah, New Jersey: Lawrence Erlbaum Associates, Publishers.

Vygotsky, L.S. (1979). Consciousness as a problem in the psychology of behaviour. Soviet Psychology 17(4), 3-35.

Vygotsky, L. S. (1986). Thought and language. Cambridge, Mass.: MIT Press.

White, L. (1998). Getting the learners' attention: A typographical input enhancement study. In C. Doughty \& J. Williams (Eds.). Focus on form in classroom SLA. 
Final Draft

Cambridge: Cambridge University Press.

Williams, J. (2005). Form-focused instruction. Handbook of research in second language teaching and learning. Mahwah, N.J.: Lawrence Erlbaum Associates, Publishers.

Wood, D. (1992). Teaching talk. In K. Norman (Ed.), Thinking voices: The work of the National Oracy Project (pp.203-214). London: Hodder \& Stoughton (for the National Curriculum Council).

Wood, D., Bruner, J.S., \& Ross, G. (1976). The role of tutoring in problem-solving. Journal of Child Psychology and Psychiatry, 17, 89-100.

\section{Appendix}

\section{Transcription Conventions}

*Each line in the transcript represents one tone group uttered by the participants.

\section{Symbols Meaning}

$\mathrm{T} \quad$ The teacher

S1, S2, .. Different students in consecutive turns distinguishable by their different voices Ss $\quad$ A group of students

$<$ To invent $>$ English translations following words uttered in Cantonese

( ) Researcher's comments

- Falling intonation followed by noticeable pause (as at the end of declarative sentences)

(.) Short pause

, Continuing intonation

? Rising intonation, usually a question

A-B-C-D Sounding out the letter names of a word as in spelling

CAPITALS Emphasized utterances

textbook Utterances directly reproduced from published texts, or teaching materials 


\section{Final Draft}

\section{Notes:}

1. The title of the project is "Attention to language knowledge and attention to language use within the English language curriculum.” It was supported by the Internal Research Fund of The Hong Kong Institute of Education from 2005-2007.

2. In these joint planning meetings, the teachers would propose initial ideas and plans for the research lessons and invite comments and suggestions from their respective researcher-partner. The teachers, however, had full autonomy to decide whether the researchers' suggestions would be taken.

3. It was the intention of the project to conduct the interviews as soon as possible after the lessons but due to practical constraints, these interviews were usually conducted during recess and lunch hours. Each interview thus lasted about 5 minutes.

4. Both authors of this paper were co-researchers in the project. The first author was not involved in Ronnie's action research, but all researchers have access to the project data from the five teachers.

5. In the year 2006 when the assessment was first administered, $92.7 \%$ of the candidates attained level 3 for classroom language, whereas only $45.9 \%$ attained the same level for writing, and another $37 \%$ for speaking.

6. There are four different meanings and uses of the word "last" in Cambridge Advanced Learner's Dictionary (2003) whereas dictionary.com has recorded nine.

7. Due to the special interest of the first author in classroom discourse analysis, both authors were involved in the post-data-collection interview with Ronnie.

8. Most Hong Kong teachers have a tight teaching schedule, and the project teachers usually could spare only one free period (80 minutes maximum) for the SRI, and most teachers had to be involved in extra-curricular activities and/or other teaching-related duties after school.

9. The second author is more interested in investigating the pedagogical design and professional development of the project teachers.

10. In the post-data-collection interview, Ronnie did express her gratitude that she had improved a lot in her teaching methodologies after the action research. She now realized that input on language knowledge need not be presented all by the teacher before students did grammar exercises or tasks, but could be acquired by students through being meaningfully engaged in tasks.

11. We were, however, heartened to see that Ronnie was indeed very receptive to comments and feedback when we brought her attention to the "problems" revealed by the transcripts. Even though she looked a bit embarrassed, she welcomed this chance to have her awareness raised. 